\title{
Main challenges and opportunities in Higher Education to promote sustainable development goals. The effectiveness of digital teaching methods in times of COVID-19
}

Belén López ${ }^{1}$

Communication Department, ESIC University; ESIC, Business \& Marketing School, 28223 Madrid, Spain
belen.lopez@esic.university; Tel.: +34-91-452-4100

\begin{abstract}
The Coronavirus (COVID-19) pandemic has created big challenges and opportunities in Higher Education (HE). In this situation, several universities worldwide have responded with digital methods and hybrid classes in a short period of time. The aim of this paper is to show how the universities have adapted teaching methods to digital platforms in the academic year 2020-21. This case study is based on the experience of 37 postgraduate communication students in the course Business and Communication from a Communication Programme. The objective of this course was to promote the 17 sustainable development goals (SDGs) in business and following the Principles for Responsible Management Education (PRME) of the United Nations. To do this, the students provided different solutions related to the SDGs and developed a communication strategy to inform and engage the stakeholders in the companies analyzed in a hybrid class. The results show that using this methodology and working in digital platforms, students have learned the importance of SDGs through implementing specific solutions linked to the corporate social responsibility (CSR) strategy. Based on this analysis, they also developed a communication strategy showing how companies can improve society with specific actions through the lens of the SDG perspective.
\end{abstract}

Keywords: digital methods; student-centred learning; higher education; sustainable development goals; corporate social responsibility; CSR communication.

\section{Introduction}

Recent literature explores the opportunities and challenges for Higher Education (HE) in teaching methodologies using hybrid classes [1], as a consequence of the global health pandemic. Digital platforms have been implemented to engage students with teaching methods based on student-centred learning [2]. Although this new scenario had different impacts on the educational system and its methodologies [3,4], the adaptation of universities to online teaching highlighted several benefits for students [5]. One of the challenges for HE institutions was to create content and engage students in a digital system [6,5] using videos, social media content and online tutorials, among other tools [7]. 
All of this required greater involvement of students in their learning. As a consequence, students had a transformative learning opportunity to consume content and classes through digital platforms [85] and adapted to these new learning methods [8].

In addition, and related to global demands and sustainability [9], HE has committed students to develop capacities to apply knowledge with a social purpose in solving problems that affect people and the planet. This perspective, which is defined in the 17 Sustainable Development Goals (SDGs) and Principles of Responsible Management Education (PRME) from the United Nations, serves to work with students in their roles as students and citizens, as they learn about and understand the connection between business and society. The SDGs reflect how companies can integrate the 17 issues in different areas of their corporate social responsibility (CSR) strategy. Therefore, companies can report their contribution to society based on global issues such as equality, climate change and responsible consumption, among others.

Furthermore, SDGs represent a challenge for HE [10] to engage students in the global issues reflected in the 17 goals. In this sense, the current pandemic is an opportunity to analyze, explore and experience teaching methods to impact the SDGs [11,12]. Moreover, students can better understand the CSR of companies, their connections with sustainable activities and the solutions firms provide in this area. Therefore, students can better explore how companies implement their social, economic and environmental activities following their CSR strategies. They report their results connecting the SDGs and explaining their impacts on stakeholders [13]. Furthermore, students can learn and collaborate with communities and projects with a social purpose [14].

The main objective of this case study is to explore the teaching methods of HE in a hybrid system caused by COVID-19, where face-to-face teaching was reduced to $50 \%$ of students in the classroom. The experience was developed at ESIC University in the fall semester of the academic year 2020/2021 with 37 postgraduate communication students in the course Business and Communication part of the Official Master of Communication. Their group projects were based on developing a CSR strategy providing different business solutions related to the 17 SDGs and they also developed a communication strategy to explain the company CSR strategy for the next year explaining the future contribution of the company to the SDGs.

The results show that this teaching methodology was effective in the students' learning because they made some strategic decisions including the company environmental and social impacts and they explained how they will contribute as responsible managers in the field of CSR/Sustainability. Also, they developed a communication strategy using different messages and channels to engage stakeholders of the companies with global issues implementing specific solutions to benefit the society.

This paper is a contribution in specific aspects. Firstly, it is a contribution to the literature on cases developed in HE using methodologies that involve students in making decisions with sustainable criteria. In addition, this paper also shows how hybrid classes can effectively help the development of useful competencies of students, both for academia and the community. Finally, this paper is based on a case study about the link between business and society through the CSR strategy and how companies can 
implement the SDGs to benefit society by measuring and reporting their impacts through their communication tools.

This article is structured as follows. Firstly, a review of the literature has been carried out in the areas of digital methods in HE, SDGs, CSR and CSR communication. Secondly, the methodology followed is described including the sample of companies analyzed by the students and it is based on case studies. Thirdly, the results obtained are summarized according to the students' project objectives. Lastly, the conclusions and discussion are included in the last section of the paper.

\section{Literature Review}

\subsection{Digital teaching methods in Higher Education}

The pandemic caused by COVID-19 has created big challenges in HE with limitations in face-to-face teaching. As a consequence, innovation has been a key element in HE to adapt teaching methods during the global health crisis. Therefore, universities worldwide have developed digital methods creating an educational system to engage students using methods based on student-centred learning [2] in collaborative learning [15] in hybrid classes [1]. In this context, teachers have innovated using tools such as videos, social media content, online tutorials, among others [7], to engage their students.

Although analysis of the impact of COVID-19 in the educational system is scarce $[3,4]$, in general, HE has adapted very quickly to a digital system and thousands of teachers worldwide can teach effectively online via Zoom [16]. Based on this experience, online teaching represents an opportunity to scale up teachers' training in online teaching improving student learning in $\operatorname{HE}[17,18]$ with different methods adapted to the new digital platforms.

In this context, some scholars argue that e-learning has several benefits, such as accessibility, flexibility, learning pedagogy and life-long learning [5], is engaging for students and uses innovative digital methods [6,5]. However, online teaching requires students to have a capacity for self-disciplined for active learning in a digital environment. Also, the pandemic has shown that the objectives of learning in HE should achieve learning outcomes and also social and emotional aspects related to the learning experience [4].

\subsection{Connecting sustainability and corporate social responsibility with Higher Education}

One of the goals of HE teaching today is to engage the students with socio-ethical capacities to build students/citizens to use their knowledge for social impact. This means that education should work in community and classroom spaces to connect education with social problems [19]. In this sense, the PRME principles and the sustainable development goals promoted by the United Nations (UN) represent a challenge for universities to rethink concepts, such as social justice, gender equality and climate change, among other global issues linked to sustainable development. Therefore, it is vital that students acquire the knowledge and skills to solve social problems reflected in the 17 SDGs and connected with the PRME principles for HE institutions promoted by the UN to create responsible universities including principles such as i) purpose, ii) values, iii) methods, iv) research, v) partnership and vi) dialogue with stakeholders. 
As a consequence, sustainable development becomes a challenge in the field of $\mathrm{HE}$ [10]. Therefore, the pandemic represents the opportunity to explore different teaching methods to make real contributions from HE to the SDGs [11,12] following institutional recommendations including from the European Union to include sustainability in the student curriculum [20]. Hence, the SDGs represent an excellent opportunity for building a community where students, from a responsible perspective, study and collaborate for a social purpose [21].

In addition, universities have included the concept of CSR in business, considering the economic, social and environmental perspective of companies in relation to business and society [22]. This concept is defined by the European Union as the responsibility of enterprises for their impact on society [23], pointing out that companies can be socially responsible integrating ethical, social and environmental issues into their business strategy, communicating their commitments and results through different channels.

CSR has been increasingly studied in the last twenty years [24]. It is connected with certain theories, such as the stakeholder theory [25], and is linked to the business implications of implementing a CSR strategy in a company [26]. In addition, some authors have studied the connection between CSR strategies and the implementation of the 17 SDGs in a business strategy, providing solutions for the development of society, as occurs with SDG1, poverty reduction [27].

In the post-pandemic context, CSR becomes an area of study because the stakeholders expectations are connected to the solutions that companies can provide to the global problems related to the SDGs [13]. Hence, this concept is based on how companies measure their impacts and how the firms create shared value [28]. From an HE perspective, the courses focus on CSR, Business Ethics and Sustainability, among others, and have the challenge of adapting knowledge and skills of students for a social purpose looking for a positive impact.

In other words, the relationship between CSR and corporate performance, management and sustainable growth is part of the academic and business debate on CSR and its impacts [29-35]. Moreover, some scholars have studied the relationship between CSR benefits for companies and their stakeholders [36,37] and how they can positively impact the environment [38]. Also, measurement of CSR implies knowing the impact on other variables, such as economic and social variables and corporate governance [39]. In sum, stakeholders are demanding more sustainable actions of companies and evidence from their impacts to better understand how companies contribute to society [40].

\subsection{CSR communication}

In the global context, in which CSR has been implemented by companies, CSR communication has also been studied to understand how firms communicate their CSR activities, sustainable commitments and impacts. Additionally, communication serves to create an engagement with stakeholders [41] through different channels, such as corporate websites, social media and traditional media, among others. Firms use messages and information to explain what they do and how they create value for their stakeholders $[28,42]$. In general, studies show that companies are not using communication channels to create a dialogue on social media [43]. In this way, companies can increase participation 
on social platforms [44] exploring issues of interests to their stakeholders creating engagement with the firm [45] and interaction with the companies [46] on sustainable issues.

Furthermore, the impact of companies' CSR communication is important to determine how companies really contribute to society through their CSR strategies. In addition, companies report their results linked to the different SDGs, consequently increasing information and transparency in their business management [47].

All this has an impact on the teaching of CSR in a digital world, with the aim of training students in the CSR of companies as a business model, CSR communication and how to increase a positive impact on society through measurable actions related to the SDGs $[48,49]$.

\section{Methods}

The objective of this paper is to show how teaching methods can provide business solutions to better understand the contribution of companies from a sustainable perspective in hybrid classes.

This study is based on the evaluation from 37 postgraduate communication students in the Business and Communication course in the academic year 2020-21. Through a content analysis, the competences included in the program have been linked to the objectives of the course project. For this, an evaluation method was used that ensured the learning objectives connected to the repositioning of the CSR strategy of the companies in the sample. To do this, the students provided different business solutions related to the 17 SDGs and developed a communication strategy to inform and engage their stakeholders.

The aim of these activities was to reinforce the professional competencies of students in hybrid teaching with a social purpose and linking CSR with SDGs and CSR communication. Business and Communication is a subject from the DCNT programme (Master in Communication Management and New Technologies) where the main competences of the subject are: i) Basic and general skills: CG01 - Demonstrate a systematic understanding of the communication management processes in organizations, mastering the skills and codes used in the communication of companies and institutions. CG02 - Capacities and abilities necessary to obtain and manage those useful information sources to continue their own training development in the field of communication management and direction. CG03 - Ability to carry out a critical analysis and the evaluation and synthesis of new and complex messages in the fields of conventional (offline) and digital (on-line) communication. CG05 - Ability to generate critical thoughts from the knowledge acquired. The student will generate judgments that allow a reflection on the form, content and ways of managing communication. ii)Transversal competencias: CT01 - Promote and develop teamwork with responsibility and commitment. CT02 Promote and encourage interpersonal communication and the ability to speak in public. CT03 - Foster flexibility and the ability to adapt to change. CT04 - Enhance the ability to communicate and interact with colleagues, with the academic community as a whole and with society in general, promoting their social skills. iii) Specific competencias: CE01 Mastering the codes and terms of communication, conventional and digital, of organizations with society. CE05 - Know the responsibilities of the Communication 
Department regarding intangible assets, such as sustainability, internal communication or corporate social responsibility. CE13 - Mastering the basic legal concepts and aspects that encompass the jurisprudence applied to the sector, paying special interest in those basic competences for professional practice.

The evaluation method consisted of delivering the project in a written document and making a 20-minute group presentation explaining the strategy to be developed, arguing a strategy with the specific objective of connecting SDGs with the CSR strategies and following this structure: i) Introduction: project justification, ii) Purpose: a repositioning of the CSR strategy including lines of action related to social and environmental issues and its contribution to the SDGs, iii) Design: an integrated communication plan including aspects such as targets, messages, channels and KPIs of the communication plan, iv) Conclusions. All this was carried out in the pandemic context where the students followed lecturers and tutoring in the hybrid system (1 week at home, 1 week in class).

The evaluation criteria of the course has been similar to other courses of the programme where lecturers give feedback about the projects following these criteria: i) theory and understanding (20\%), ii) analysis and model implementation (25\%), iii) solutions, conclusions and contributions (40\%), iv) style and structure (15\%), and, finally, observations about the group presentation.

In addition, the consistency of the actions proposed by the students is also considered in the evaluation, as well as the viability of the proposed actions and the identification with the company, considering previous actions as well as the communication of each company.

Although the companies of the sample already contribute to the SDGs (El Corte Inglés, Google, Grupo Quirón Salud, Mercadona, Iberdrola, Santander, Telefónica and Mutua Madrileña), a repositioning towards the activism of the firm was presented to make the highest contribution with concrete measures on their impacts. Thus, students contributed with their proposals to accelerate the impact of these companies related to the 2030 Agenda.

Further, the overall objective was to analyze the strengths and weaknesses of each company planning a new positioning, which was built with a long-term objective. In addition, each group had the objective of increasing social and environmental commitments, in accordance with the 17 SDGs. Finally, the students' proposals included a communication strategy to explain the commitments made by the company and to engage different stakehoders to the strategy.

\section{Results}

All the groups presented a report including the activities connected to the CSR strategy of the companies and focusing on one specific SDG (see Table 1). The SDGs selected for the analysis are: SDG 3, SDG 4, SDG 7, SDG 8, SDG 10, SDG 11, SDG 12, and SDG 17. 
Table 1. Companies and SDGs selected for the final project

\begin{tabular}{|c|c|c|}
\hline Company & SDG & Description \\
\hline El Corte Inglés & 11 & $\begin{array}{l}\text { Make cities and human set- } \\
\text { tlements inclusive, safe, resil- } \\
\text { ient and sustainable }\end{array}$ \\
\hline Google & 8 & $\begin{array}{l}\text { Promote sustained, inclusive } \\
\text { and sustainable economic } \\
\text { growth, full and productive } \\
\text { employment and decent } \\
\text { work for all }\end{array}$ \\
\hline Grupo Quirón-Salud & 17 & Partnerships for the Goals \\
\hline Mercadona & 12 & $\begin{array}{l}\text { Ensure sustainable consump- } \\
\text { tion and production patterns. }\end{array}$ \\
\hline Iberdrola & 7 & $\begin{array}{l}\text { Ensure access to affordable, } \\
\text { reliable, sustainable and } \\
\text { modern energy for all }\end{array}$ \\
\hline Santander & 3 & $\begin{array}{c}\text { Ensure healthy lives and pro- } \\
\text { mote well-being for all at all } \\
\text { ages }\end{array}$ \\
\hline Telefónica & 4 & $\begin{array}{l}\text { Ensure inclusive and equita- } \\
\text { ble quality education and } \\
\text { promote lifelong learning op- } \\
\text { portunities for all }\end{array}$ \\
\hline Mutua Madrileña & 10 & $\begin{array}{l}\text { Reduce inequality within } \\
\text { and among countries }\end{array}$ \\
\hline
\end{tabular}

Source: Final Project DCNT 2020-21

The evaluation shows the students' commitment to the projects since all the groups obtained a grade equal to or greater than 7 . In addition, the quality of the proposals was consistent with the CSR strategy of the companies of the sample and, in general, the students made professional presentations, where $100 \%$ of students exposed their projects in a face-to-face- presentation.

In general, the objectives established in the project are met by gathering students' knowledge, skills and competences, while becoming aware of the needs of society. Therefore, the experience had an impact on the students as professionals and individuals.

Regarding individual degrees distributed by gender, the following aspects are highlighted: considering the total of 37 students, 23 are women. This is a fact that is repeated even in previous years, that is, a greater number of women in the Master of Communication. In fact, the profile of this programme is a 23-year-old woman with two years of experience in the labour market. All students in this project obtained a grade higher than 70 points and it should also be noted that the best grades were also obtained by women, as can be seen in Table 2 .

Table 2. Final Project Grades 


\begin{tabular}{cccc}
\hline GRADES & Male & Female & Total \\
\hline $60-69$ & 0 & 0 & 0 \\
\hline $70-79$ & 6 & 7 & 13 \\
\hline $80-89$ & 6 & 13 & 19 \\
\hline $90-99$ & & & 5 \\
\hline
\end{tabular}

Source: Final Project Evaluation

The DCNT Master was in its eighth edition and is the first of its kind according to the El Mundo Ranking for five consecutive academic years. According to the latest study carried out by ESIC, it has $100 \%$ employability among its students, one year after finishing it. These students have professional experience and their main objective is working in the communication area of a large multinational company. In general, between 35-40 students take the DCNT Programme every year (table 3).

Figure 1 - Number of students in DCNT Programme

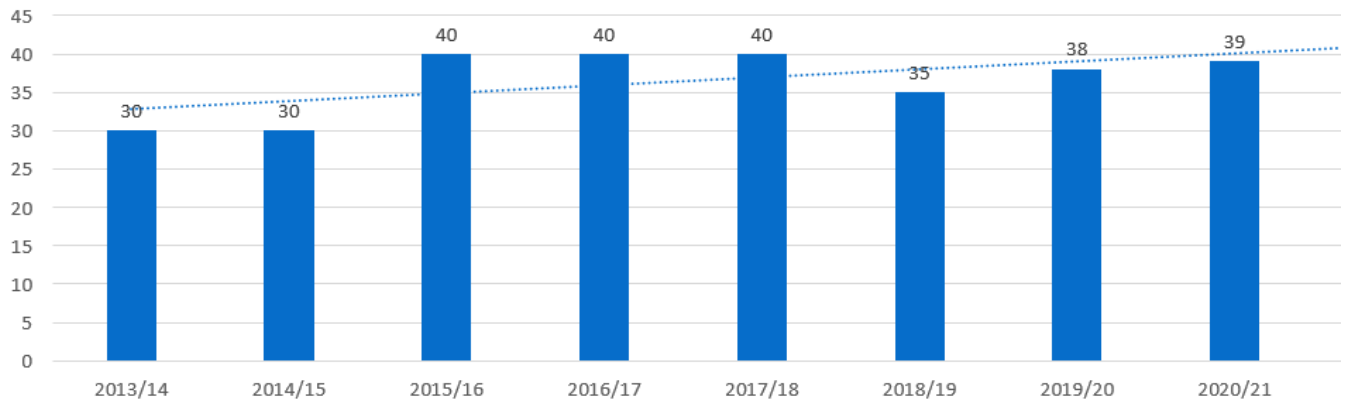

Source: ESIC University.

The reputation of the programme is based on the word-of-mouth (WOM); $70 \%$ of the students who study each year will do so following recommendations from former students of the master's degree and/or ESIC and professors from other Spanish universities. The faculty is made up of professors from ESIC University, with extensive experience in the business world. 
The programme is aimed at those people who want to work in organizations from the perspective of corporate communication, advertising and marketing, knowing how to handle all the tools that make possible the new technologies used in the professional field. The objective is to acquire the managerial skills necessary to manage daily situations in a communication company, both to regulate communication internally and to external agents and interest groups and, above all, to know how to anticipate changes and more adverse scenarios, through the study of crisis cases and communication situations. A further objective is to understand the complete operation of the field of advertising, its approach, evaluation and analytical methods for its development and impact on the company.

In relation to the evaluation of the projects, the teacher's comments in the feedback to the students are detailed below:

1. El Corte Inglés. The work is well planned based on the indications of the CSR Director, which gives it a realistic vision of the company. The students present actions that promote the public perception of a sustainable brand. In a concrete way, sustainable tourism is the activist part involving a responsible consumer who wants to express their behaviour linked to sustainability.

2. Google. Excellent proposal. This work fulfils the proposed objective, which is repositioning a brand from CSR towards activism in a social context where brands can add great value. The students in this group properly connect all the sections and show knowledge on the subject and how to implement ideas in the company. The internal and external communication proposal is consistent with Google's activity and, therefore, its development is feasible. The communication proposal is clear, easy to remember and linked to the company's purpose.

3. QuironSalud. The theoretical framework is adequately justified, as well as giving a brief explanation of the SDGs. The CSR strategy, analysis and outstanding actions are explained, as well as all the external and internal communication channels of the company, content supported by the information provided in the interview with the Director of Communication and Marketing of QuirónSalud, as well as the interview with the Head of the Pediatrics and Neonatology Service and an interview with an ICU nurse.

The actions carried out by the company during the pandemic are also explained. And then the activist repositioning is proposed considering the disorders caused by the pandemic in the population. It also explains SDG 17, in terms of the idea of public-private collaboration, which is an important challenge in Spain, taking into account the organization of health in two clearly differentiated areas, although the proposal is necessary as a consequence of the social needs caused due by the pandemic in the population.

4. Mercadona. Argued in a very solid way, both the theoretical framework and Mercadona's current strategy as well as the repositioning proposal linking with different stakeholders. All the actions that are proposed for Goal 12 and its different objectives are clearly justified to bring the brand closer to a real activism away from a goal such as improving the image of the company. In addition, survey data, knowledge of the young public, linkage of food with different aspects closely linked to sustainability are added, providing a very solid analysis. 
The linking proposal and the graphics are directly linked to the activism that is to be promoted in the different stakeholders, the proposals being clear, providing ideas and visibility about the brand's activism on different platforms, very well illustrated in communication channels. The desired impacts are also clearly explained and well-argued by students.

5. Iberdrola. The work is well-argued and students develop an activist strategy that allows the company to evolve towards that repositioning, the objective of the work. It is well analyzed and the proposals are timely and the communication plan is well developed with visual proposals that can capture the attention of the public to fulfil the activist objective of the company. Therefore, it is a consistent proposition. However, the budget should be realistic and closer to the proposal.

Communication is easily associated with the company; "illuminates empty Spain" is a well-planned objective in relation to SDG 7. Furthermore, future lines of research are proposed and well-argued by the students.

6. Santander. The document is well explained, but some aspects could have been reflected better. The fact of putting the interviews and the survey in annexes with hardly any mention in the document is a mistake since this work helps us to better understand why video games have a positive impact on health. In the interviews, it is necessary to know Santander's vision of video games and their link with SDG 3. Only three stakeholders with whom you are going to work are mentioned, but other stakeholders of the bank should be explained. Sure, with employees it can have an impact, as explained, but only using these activities with young audiences will not necessarily work to generate commitment. The budget is detailed but it is high and such a high investment is not justified; how it will impact the bank in a concrete way, this information is important. What is the return on that investment? We do not know. On the other hand, the actions are well planned in relation to SDG 3, but they are simply actions to gain the trust of the public. It is important to distinguish the impact of the actions and the long-term goal. Overall, it is well planned, but the strategy should be more comprehensive given the budget to be allocated for it.

7. Telefónica. The theoretical framework is adequately raised with contributions from the academic literature to understand why activism is present in companies. Telefónica's current strategy is adequately explained and clear actions are proposed for activist repositioning. However, it is not well understood that the objective of reaching depopulated Spain is only limited to several geographical areas (Castilla-La Mancha, etc.) when depopulation affects the whole of Spain and the company operates throughout the national territory. Therefore, although the lines of action are clear and well planned; however, it would be desirable to extend the geographical limitation to include the rest of the unpopulated areas of Spain. With all this, the budget is very high. And it is not clear in what specific way the return on investment will be evaluated to know to what extent investment has had an impact on the organization. The communication proposal is in line with Telefónica's communication.

8. Mutua Madrileña. The theoretical framework and the company's CSR strategy are explained in detail, linking the different departments of the organization, as well as their commitment to the SDGs. Many activities are detailed on the actions carried out by the 
company and the repositioning is based on information from previous research conducted on more than 400 respondents from the general public and customers. But what is proposed is to continue with everything that the company already does. It is a continuity strategy that is proposed in the communication plan, and thus the students arrive at a proposal for activist repositioning in the reduction of inequalities. The company's CSR campaigns will follow the \#Equality proposal, ensured in various actions aimed at different interest groups. The communication proposal is clear, with a set of actions well explained. However, the budget is very low for the number of actions that are proposed (it must be adjusted, in this case, because it involves a higher budget to carry out this number of proposed actions).

In conclusion, we can highlight the following results: i) The groups explained their strategies to impact the SDG assigned and linked to the CSR strategy of the company; ii) The students explained different activities and some of them detailed how they will measure its impacts; iii) The groups developed a clear communication strategy to communicate what the company is doing in this area; iv) The students explained clearly the strategies showing good communication skills.

\section{Discussion}

The challenges and opportunities for $\mathrm{HE}$ are increasing in the post-pandemic situation in a hybrid system where students can follow their classes online and offline. In this context, teachers can engage the students using different tools and methods that invite students to provide business solutions considering social and environmental impacts; all this, considering a society demanding responsible behaviours from firms.

Thus, universities have the responsibility of engaging students using some methods based on student-centred learning [2] in collaborative learning [15] in hybrid classes [1] adapting competencies, learning outcomes and social aspects [4] including the benefits of e-learning lecturers [5]. Hence, the SDGs represent an opportunity for building a community where students can collaborate for a social purpose [21] based on CSR strategies analysed by the students providing activities to benefit society.

With the aim of reinforcing learning about sustainable development, a final project was designed where students had to carry out an activist repositioning strategy to reinforce their commitment to the SDGs. The design included a communication plan to give visibility to the actions to be carried out. In this case, learning occurs because, following the parameters of the European and Spanish education system linked to the sustainable development goals, students experience the opportunity to offer solutions combining theory and practice.

Thus, the learning linked to solutions with social impact, the quality of the projects and the involvement of the students, together with the good presentation of projects, have yielded excellent results. With all this, learning related to the oral and written discussion, the ability to make decisions and the ability to defend their approaches in the presentation are competences reinforced by the students after doing this course. As a consequence, this learning methodology links knowledge with social needs and, in this way, students reinforce useful skills for their professional performance with social impact. 
Future research offers opportunities to explore other methodologies with students based on transformative learning, such as making proposals as citizens in responsible consumption, etc. The impact of the actions they will provide can also be explored with a methodology measured in the long term, in order to know what happened in the companies one year after applying the proposed actions. Finally, students can also select the best practices to propose successful practices to other companies to fight against climate change, among other issues. All this has a social purpose, to contribute to sustainable development in various areas, both individually and in groups, as professionals and citizens.

In addition, the measurement of this experience in student learning can go further. For example, evaluation sheets can be used with surveys to students at the beginning and at the end of the course, measuring the level of engagement with the SDGs in the process. They can also use self-assessment tests, useful for students and teachers, on this subject. In turn, students can report which activities carried out in each subject have served to reinforce their competences and skills. All this will result in dynamic teaching that is committed to activating the students, especially as a consequence of the appearance of a hybrid teaching system.

\section{Conclusions}

The teaching methodology on the DCNT Master to explain CSR, SDGs and CSR communication in business management is as follows. First, the professor begins the class by discussing different cases [50] generating a discussion from the beginning that is complemented with the explanation of concepts, theories and virtual tutorials to carry out the work of the subject. In this sense, the hybrid methodology represents a challenge for teachers as well as using different materials for the class. To achieve an adequate adaptation, training and generating collaborative spaces between teachers allow rapid and efficient learning to experiment with students in the classroom.

As a consequence, students increase their knowledge about how companies face global problems, materialized in the SDGs, they know how firms report on SDGs and how firms involve their stakeholders to accelerate their contributions by being activists for social and environmental improvement. Finally, this case study is an example of how a CSR strategy together with a communication strategy are competitive for companies to explain what and how they develop their commitments to sustainability.

This study has some limitations. First, the sample is limited to a single group, with the responses of 37 students being analyzed. Second, only group contributions are considered, so more attention has been paid to collective rather than individual aspects of learning. Finally, the course begins with a little knowledge about the SDGs that is expected to increase at the end of the course, but the level of progress is only measured with the described project not using other assessments, such as individual essays.

Although the initial knowledge is limited, in general, it can be noted that at the end of the course students know better how companies implement their CSR strategy. They also explore different CSR communication tools. In addition, they analyze how companies can increase their commitments to society and how they can connect CSR activities with the SDGs. In turn, students develop a communication strategy to engage stakeholders. 
And, finally, they know the contributions that companies can make through the 17 SDGs. As a consequence of all this work, the students also feel closer to the SDGs and society.

Based on this experience, future students can improve their learning and skills by collaborating with companies in the application of their proposals, both in their analysis and in the suitability of their implementation following the criteria established by the companies.

In turn, the evaluation provided by the teacher can be complemented by professional feedback from the firms, who should evaluate the abilities of the students in providing solutions to real problems with their proposals considering contributions by gender.

Finally, it would be desirable to carry out a pre-test of the communication campaigns proposed by the students to assess whether their objectives are clear for potential stakeholders in order to check their possible impact. All this can be developed both in a hybrid system and in a face-to-face system, since technologies allow communication between students and professors.

Acknowledgments: I want to thank the students of the DCNT program of the academic year 2020-2021 for the contributions made in their final project, through coherent proposals for the business contribution to the SDGs.

Funding: This research received no external funding.

Conflicts of Interest: The author declares no conflict of interest.

\section{References}

1. McMurtrie, B. Teaching: How To Engage Students in a Hybrid Classroom. Newsletter: The Chronical of Higher Education, 2020.

2. Kolb, D. A. Experiential learning: Experience as the source of learning and development. FT press. 2014.

3. Bao W. COVID-19 and online teaching in higher education: A case study of Peking University. Hum Behav \& Emerg Tech., 2020, 1-3. https://doi.org/10.1002/hbe2.191

4. Zhu, X.; Liu, J. Education in and After Covid-19: Immediate Responses and Long-Term Visions. Postdigital Science and Education, 2020, 1-5. https://doi.org/10.1007/s42438-020-00126-3

5. Dhawan, S. Online Learning: A Panacea in the Time of COVID-19 Crisis. Journal of Educational Technology Systems, 2020, 49(1), 5-22. https:// doi.org/10.1177/0047239520934018

6. Aucejo, E. M.; French, J. F.; Araya, M. P. U.; Zafar, B. The impact of COVID-19 on student experiences and expectations: Evidence from a survey (No. w27392). National Bureau of Economic Research, 2020.

7. Sandars, J.; Correia, R.; Dankbaar, M.; de Jong, P.; Goh, P. S.; Hege, I.; Pusic, M. Twelve tips for rapidly migrating to online learning during the COVID-19 pandemic. MedEdPublish, 9, 2020. https://doi:10.15694/mep.2020.000082.1

8. Blundell, C.; Lee, K. T.; Nykvist, S. Moving beyond enhancing pedagogies with digital technologies: Frames of reference, habits of mind and transformative learning. Journal of research on technology in education, 2020, 52(2), 178-196. https://doi.org/10.1080/15391523.2020.1726235

9. McLennan, M. The Global Risks Report. 16th Edition, 2021. Retrieved from: https://www.weforum.org/reports/the-global-risksreport-2021. 
10. Muftahu, M. Higher Education and Covid-19 Pandemic: Matters Arising and the Challenges of Sustaining Academic Programs in Developing African Universities. International Journal of Educational Research Review, 2020, 5(4), 417-423. https://doi.org/10.24331/ijere.776470

11. Pan, S. L.; Zhang, S. From fighting COVID-19 pandemic to tackling sustainable development goals: An opportunity for responsible information systems research. International Journal of Information Management, 2020, 102-196. https://doi.org/10.1016/j.ijinfomgt.2020.102196

12. Pan, S. L.; Pee, L. G. Usable, in-use, and useful research: A $3 U$ framework for demonstrating practice impact. Information Systems Journal, 2020, 30(2), 403-426. https://doi.org/10.1111/isj.12274

13. Lopez, B. Connecting business and sustainable development goals in Spain. Marketing Intelligence E Planning, 2020, Vol. 38 No. 5, 2020 pp. 573-585. https://doi.org/10.1108/MIP-08-2018-0367

14. Muñoz-Rodríguez, J. M.; Sánchez-Carracedo, F.; Barrón-Ruiz, Á.; Serrate-González, S. Are we training in Sustainability in Higher Education? Case Study: Education Degrees at the University of Salamanca. Sustainability, 2020, 12(11), 4421. https://doi.org/10.3390/su12114421

15. Kim, K.-J.; Bonk, C. J. The future of online teaching and learning in higher education: The survey says. Educause Quarterly, 2006, 4, 22-30.

16. Yan, Z. Unprecedented pandemic, unprecedented shift, and unprecedented opportunity, 2020. https://doi.org/10.1002/hbe2.192.

17. Ludeman, R.; Osfield, K.; Hidalgo, E. I.; Oste, D.; Wang, H. Student Affairs and Services in Higher Education: Global Foundations, Issues and Best Practices. United Nations Educational, Scientific and Cultural Organization, France. 2009. Retrieved from https://unesdoc.unesco.org/ark:/48223/pf0000183221

18. Toquero, C. M. Challenges and Opportunities for Higher Education Amid the COVID-19 Pandemic: The Philippine Context. Pedagogical Research, 2020, 5(4). https://doi.org/10.29333/pr/7947

19. Peters, M. A.; Rizvi, F.; McCulloch, G.; Gibbs, P.; Gorur, R.; Hong, M.; Misiaszek, L. Reimagining the new pedagogical possibilities for universities post-Covid-19: An EPAT Collective Project. Educational Philosophy and Theory, 2020, 1-44. https://doi.org/10.1080/00131857.2020.1777655

20. Farnell, T. 'Community engagement in higher education: trends, practices and policies', NESET report, Luxembourg: Publications Office of the European Union, 2020. http://doi: 10.2766/071482.

21. Muñoz, R. M.; Fernández, M. V.; Salinero, Y. Sustainability, corporate social responsibility, and performance in the Spanish wine sector. Sustainability, 2020, 13(1), 7. https://doi.org/10.3390/su13010007

22. Carroll, A.B.; Buchholtz, A.K. Business and Society. In Ethics, Sustainability, and Stakeholder Management, 9th ed.; Cengage Learning: Boston, MA, USA, 2014.

23. European Commission, renewed EU strategy 2011-2014 for Corporate Social Responsibility. Communication from the Commission to the European Parliament, the Council, the European Economic and Social Committee and the Committee of the Regions, Brussels, COM, 681(25.10), 2011.

24. Carroll, A. B. Corporate Social Responsibility: Perspectives on the CSR Construct's Development and Future. Business $\mathcal{E}$ Society, 2021. https://doi.org/10.1177/00076503211001765

25. Freeman, R. E. A stakeholder theory of the modern corporation. Perspectives in Business Ethics Sie, 2001, 3(144), 38-48.

26. Kolk, A. The social responsibility of international business: From ethics and the environment to CSR and sustainable development. Journal of World Business, 2016, 51(1), 23-34. https://doi.org/10.1016/j.jwb.2015.08.010

27. ElAlfy, A.; Palaschuk, N.; El-Bassiouny, D.; Wilson, J.; Weber, O. Scoping the evolution of corporate social responsibility (CSR) research in the sustainable development goals (SDGs) era. Sustainability, 2020, 12(14), 5544. https://doi.org/10.3390/su12145544

28. Porter, M. E.; Kramer, M. R. Creating shared value. In Managing sustainable Business, 2019, 323-346. Springer, Dordrecht. https://doi.org/10.1007/978-94-024-1144-7_16

29. Korhonen, J. Should we measure corporate social responsibility? Corporate Social Responsibility and Environmental Management, 2003, 10(1), 25-39. https://doi.org/10.1002/csr.27 
30. Cho, S.; Chung, C.; Young, J. Study on the relationship between csr and financial performance. Sustainability, $2019,11(2), 343$. https://doi.org/10.3390/su11020343.

31. Hernández-Perlines, F.; Ariza-Montes, A.; Araya-Castillo, L. Sustainable growth in the agro-food cooperatives of Castilla La Mancha (Spain). Sustainability, 2020, 12(12), 5045. https://doi.org/10.3390/su12125045

32. Kamran, H. W.; Pantamee, A. A.; Patwary, A. K.; Ghauri, T. A.; Long, P. D.; Nga, D. Q. Measuring the association of environmental, corporate, financial, and social CSR: Evidence from fuzzy TOPSIS nexus in emerging economies. Environmental Science and Pollution Research, 2020. https://doi.org/10.1007/s11356-020-11336-4

33. Partalidou, X.; Zafeiriou, E.; Giannarakis, G.; Sariannidis, N. The effect of corporate social responsibility performance on financial performance: The case of food industry. Benchmarking: An International Journal, 2020, 27(10), $2701-2720$. https://doi.org/10.1108/BIJ-11-2019-0501

34. Ye, N.; Kueh, T.-B.; Hou, L.; Liu, Y.; Yu, H. A bibliometric analysis of corporate social responsibility in sustainable development. Journal of Cleaner Production, 2020, 272, 122679. https://doi.org/10.1016/j.jclepro.2020.122679

35. Zafar, M. B.; Sulaiman, A. A. Measuring corporate social responsibility in Islamic banking: What matters? International Journal of Islamic and Middle Eastern Finance and Management, 2020, 13(3), 357-388. https://doi.org/10.1108/IMEFM-05-2019-0227

36. Panayiotou, N. A.; Aravossis, K. G.; Moschou, P. A new methodology approach for measuring corporate social responsibility performance. Water, Air, E Soil Pollution: Focus, 2009, 9(1-2), 129-138. https://doi.org/10.1007/s11267-008-9204-8

37. Turker, D. Measuring corporate social responsibility: A scale development study. Journal of Business Ethics, 2009, 85(4), 411-427. https://doi.org/10.1007/s10551-008-9780-6

38. Shahzad, M.; Qu, Y.; Javed, S. A.; Zafar, A. U.; Rehman, S. U. Relation of environment sustainability to CSR and green innovation: A case of Pakistani manufacturing industry. Journal of Cleaner Production, 2020, 253, 119938. https://doi.org/10.1016/j.jclepro.2019.119938

39. Almaskati, N.; Bird, R.; Lu, Y. Corporate governance, institutions, markets, and social factors. Research in International Business and Finance, 2020, 51, 101089. http://doi.org/ 10.1016/j.ribaf.2019.101089.

40. Barnett, M. L.; Henriques, I.; Husted, B. W. Beyond good intentions: Designing CSR initiatives for greater social impact. Journal of Management, 2020, 46(6), 937-964. https://doi.org/10.1177/0149206319900539

41. Villagra, N.; López, B.; Monfort, A. The management of intangibles and corporate branding: Has anything changed in the relationship between business and society? Revista Latina de Comunicación Social, 2015, (70), 793. http://doi.org/ 10.4185/RLCS2015-1072en

42. López, B.; Monfort, A. Creating shared value in the context of sustainability: The communication strategy of MNCs. Corporate Governance and Strategic Decision Making, 2017, 119-135. http://doi.org/ 10.5772/intechopen.70177

43. Abitbol, A.; Meeks, J.; Cummins, R. G. Does oil and goodwill mix?: Examining the oil and gas industry's impact on stakeholder engagement on Facebook. Environmental Communication, 2019, 13(2), 192-208. https://doi.org/10.1080/17524032.2018.1546751

44. Monfort, A.; Villagra, N.; López, B. Exploring stakeholders' dialogue and corporate social responsibility (CSR) on Twitter. Profesional de la Información, 2019, 28(5). https://doi.org/10.3145/epi.2019.sep.13

45. Okazaki, S.; Plangger, K.; West, D.; Menéndez, H. D. Exploring digital corporate social responsibility communications on Twitter. Journal of Business Research, 2020, 117, 675-682. http://doi.org/ 10.1016/j.jbusres.2019.09.006

46. Hartmann, P.; Fernández, P.; Apaolaza, V.; Eisend, M.; D’Souza, C. Explaining Viral CSR Message Propagation in Social Media: The Role of Normative Influences. Journal of Business Ethics, 2020, 1-21. http://doi.org/10.1007/s10551-020-04540-2

47. Jun, H.; Kim, M. From Stakeholder Communication to Engagement for the Sustainable Development Goals (SDGs): A Case Study of LG Electronics. Sustainability, 2021, 13(15), 8624. https://doi.org/10.3390/su13158624

48. Heath, R. L.; Waymer, D. University engagement for enlightening CSR: Serving hegemony or seeking constructive change. Public Relations Review, 2021, 47(1), 101958. http://doi.org/ 10.1016/j.pubrev.2020.101958

49. Tetrevova, L.; Vavra, J.; Munzarova, S. Communication of Socially-Responsible Activities by Higher Education Institutions. Sustainability, 2021, 13(2), 483. https://doi.org/10.3390/su13020483 
50. Clawson, J. G.; Haskins, M. E. Teaching management: A field guide for professors, consultants, and corporate trainers. Cambridge university press. 2006 . 